\title{
Caatinga plants with nutritional potential: a review from the work "Contribution to the study of the Flora from Pernambuco, Brazil" (1954) by Dárdano de Andrade Lima
}

\author{
Alissandra T. Nunes ${ }^{1}$, Viviany T. Nascimento ${ }^{2}$, Ivanilda S. Feitosa ${ }^{1}$, \\ Maria F. T. Medeiros ${ }^{1,3}$ and Ulysses P. Albuquerque ${ }^{1, *}$
}

\footnotetext{
${ }^{1}$ Laboratory of Applied Ethnobotany, Department of Biology, Federal Rural University of Pernambuco, Rua Dom Manoel de Medeiros s/n, 52171-900, Dois Irmãos, Recife, PE, 52171-900, Brazil

${ }^{2}$ University from Bahia State, Br 242 S/N Lot. Flamengo, PO BOX 47800-000, Barreiras, BA, 47800000, Brazil

${ }^{3}$ Pontifical Catholic University of Rio de Janeiro, School of Biological Sciences, Rua Marques de São Vicente 225, Prédio Pe. Leonel Franca, $7^{\circ}$. andar, Gávea, Rio de Janeiro, RJ, 22451-900, Brazil

* Corresponding author

\E-mail adresses: ATN (alibiol@hotmail.com), VTN (vivyteixeira1@hotmail.com), ISF (lilithbio@hotmail.com), MFTM (mariaftm@hotmail.com), UPA (upa677@hotmail.com)
}

Ethnobiology and Conservation 2012, 1: 5 (5 October 2012)

ISSN 2238-4782

doi: $10.15451 /$ ec2012-8-1.5-1-18

\section{Abstract}

ethnobioconservation.com

A historical review about the native food species from caatinga in Pernambuco state, Brazil was conducted. A matrix of the food plants was created using a primary source ("Contribution to the study of the flora from Pernambuco, Brazil", by Dárdano de Andrade-Lima) and secondary sources of past use (centuries XVI/ XVII/ XIX), contemporary (50s-70s decades) and current (from the 70 s decade) to the central work. This study has revealed the potential of the native food flora from caatinga and the importance of prioritizing the record of this information, which is proven, the number of research for nutritional analysis of these species is still limited.

Keywords: Historical ethnobotany - Historical documents - Human food Northeastern Brazil 
Nunes et al. 2012. Caatinga plants with nutritional potential: a review from the work "Contribution to the study of the Flora from Pernambuco, Brazil" (1954) by Dárdano de Andrade Lima. Ethnobio Conserv 1:5

\section{Introduction}

For many years the Caatinga has been neglected, especially due the climatic adversities that reflected the idea of a low biological richness (Giulietti et al. 2004; Albuquerque et al. 2009; Maia 2004). Recently, after several sampling efforts, literature started to value its biological potential, which had disclosed a considerable number of endemic species, which makes the caatinga a very peculiar environment (Tabarelli and Vicente 2002; Maia 2004). Such fact has attracted increasingly the interest of research in this region which covers about $10 \%$ of the Brazilian territory, representing 50\% of the Northeastern part of the country (MMA 2002; Maia 2004).

Amongst the many fields of study which focus toward the Caatinga region are the works of Ethnobotanical nature, which search amongst other aspects, to review with the local population the knowledge about the useful flora, as well as strategies for its conservation. Currently many research groups have dedicated themselves to ethnobotanical studies in the region, however, most of the publications are especially focusing toward the medicinal and lumber resources (Almeida and Albuquerque 2002; Silva and Albuquerque 2005; Monteiro et al. 2006; Albuquerque et al. 2007; Santos et al. 2008; Ramos et al. 2008; Nascimento et al. 2009), existing great gaps of information regarding other important resources, such as the nourishing resources.

This lack of information about nourishing plants may be caused by several factors. A determinative in this question is the lack of studies directed to the theme. Some aspects can be taken as modulators of the investigative choice of the researchers for other subjects in detriment of the nourishing plants theme. They may be: the incorporation of products benefited in the alimentary diet of the local population, which would provoke a disinterest of research that seeks for the knowledge and the local use of vegetal species; the use of invasive methodologies which intervene directly with the daily food consumption by the informants who have participated in the interviews; and the lack of consent of the informants in participating in the research regarding the knowledge depreciation and the use associated to the vegetable resource, which also may be an impediment in research focusing toward other categories of use. However, one of the predominant factors is the cultural change process that can be based on the little information concerning the nourishing plants. It looks like, the use of nourishing plants from caatinga may be suffering an erosion process of the local knowledge, caused, among others things, by certain cultural taboos. This erosion process ultimately lead to a barrier in the knowledge transmission, in order that the orality has constituted the traditional way of perpetuation of this knowledge (Meyer-Rochow 2009). This phenomenon may favor the restriction or even though to lead to disuse of species from the semi-arid environment. Thus, it is important to remember that the absence of ethnobotanical records has contributed so that much of the knowledge regarding the nourishing plants is being lost as time goes by all over the world (Rochow and Benno 2009).

The difficulty of recovering information regarding the native nourishing plants brings up the necessity of looking for strategies that may fill this gap of knowledge. One of the alternatives is the research carried out through the historical ethnobotany, an area of the ethnobotany which search to understand the historical people relations with plants. In this historical perspective, one of the oldest and conceptualized citations of the literature, that deals with the use of plants from caatinga, is the workmanship of Dárdano de Andrade Lima, published in 1954, "Contribution to the study of the flora from Pernambuco, Brazil". In the workmanship the author has portrayed phytogeographic, floristic and ecological aspects from Pernambuco state, 
Nunes et al. 2012. Caatinga plants with nutritional potential: a review from the work "Contribution to the study of the Flora from Pernambuco, Brazil" (1954) by Dárdano de Andrade Lima. Ethnobio Conserv 1:5

standing out the potential of use of these species. This book especially portrays the experience of 27 years of studies of Andrade Lima, being a document of great importance and relevance for the knowledge of the caatinga. Considering the secular aspect of production of the related workmanship, Andrade-Lima (1954, P. 13) when evaluating the bibliography of the vegetation from caatinga, points out the fact that "little has been written about caatingas in comparison with some other areas of the Brazilian vegetation, taking into account its regional importance". Therefore, the reasons to choose this workmanship as a source-material are justified because it is a reference of dense content about the caatinga.

This study aims to conduct a historical review of the useful species from the caatinga in Pernambuco state, especially the nourishing ones, listed in the work of Andrade-Lima (1954) in order: to evidence the existence of this type of use for the native species from the region; to verify if there was deletion or incorporation in the cast of plants from caatinga, as well as in the uses attributed to themselves, cited by Andrade-Lima with data from other secondary sources, thus pointing out the possible modifications occurred in the records written about nourishing plants throughout the time; and evaluate the nutritional value of these species based on information collected from specific literature.

\section{Material and Methods}

\section{Characterization of the primary work}

For the historical review of the useful plants of the region from caatinga, it had been selected the workmanship "Contribution to the study of the flora from Pernambuco, Brazil". This title was published in 1954, by Dárdano de Andrade Lima, researcher who had dedicated his career to the study of the Northeastern flora and even today is considered an authority on the subject (Andrade-Lima 1982).

In the related work, Dárdano briefly describes the Northeastern Brazil in a bibliographical review about the caatinga vegetation, discourses about the floristic and ecological classification and its attributes; it deals about the phytogeographical division from Pernambuco state, dividing the state into three zones: caatinga, forest and maritime zone. And finally, cites each one of the plants in the different phytogeographical regions of the state, approaching their habitat, their morphologic description and their uses recorded in his comments in the trips to Northeastern Brazil. For this study, it has been considered only the plants found in the zone from caatingas.

In the text of "Contribution to the study of the flora from Pernambuco, Brazil" the author is emphatic that adopts the division of caatinga created by Vasconcelos Sobrinho (however suggests two modifications), in which the vegetation is divided in Agreste, Sertão (backwoods) (subdivided into seven regions) and the sierras, that while not having similar features like the region we are dealing with, it has been included in such classification for being physically located within the caatinga domain (Andrade-Lima 1954). 
Nunes et al. 2012. Caatinga plants with nutritional potential: a review from the work "Contribution to the study of the Flora from Pernambuco, Brazil" (1954) by Dárdano de Andrade Lima. Ethnobio Conserv 1:5

Collection and analysis of the information in the primary and secondary sources

The following information had been reviewed: scientific name, botanical family, popular name, phytogeographic zone, nourishing use and other forms of uses. Such information had been compiled in a data base. As for the assignment of the taxa, all scientific names used by Andrade Lima had been brought up to date through the Missouri Botanical Garden's VAST (Vascular Tropicos) nomenclatural database (W3 Tropicos 2010), what allowed the localization of these species in most current works.

After the conclusion of the general list of the useful species of Andrade-Lima, it had been created a second listing composed by the endemic nourishing plants from the caatinga, which was used as base for the development of the present research. From this list, it was proceeded with comparisons of the species from the primary workmanship with those mentioned in secondary sources. The search for secondary sources was subdivided at three historical moments: previous workmanships (centuries XVI, XVII and XIX), contemporaries (50s to 70s decades) and posterior (from the 70s decade) the central workmanship, of Andrade-Lima (1954).

At a first moment, the documentary analysis was carried out with the contemporaries works which also approach the use of the plants from the caatinga. For this period, it had been considered the publications from Cesar (1956) and Braga (1976). The workmanship, "Curiosities of our flora", published in 1956 and written by Getúlio Cesar, brings up a description of plants of the useful Northeastern flora, including native and exotic species from the caatinga. Although succinct, the workmanship brings a rich quarrel for the native species, with complementary information of great value for this work. The second publication, the workmanship of Renato Braga, "Northeastern Plants, especially from Ceará", in its 4th edition 1976, presents a vast list of species of native and exotic useful plants from the region, with several indications of use.

Continuing the analysis, it had been considered as previous sources to the year 1954 the works: "Descriptive treaty from Brazil" by Gabriel Soares de Sousa (1971), "Historia Naturalis Brasilae" by Guillerme Piso and Jorge Macgrave (1648 cited Pickel, 2008), "Flora Brasiliensis" published by Carl Friedrich Philipp von Martius (1840) and "Manuel Arruda da Câmara: collected works" (1982), which brings documents produced by this naturalist and investigator of the Northeastern backwoods from Brazil during the second half of the XVIII century and the beginning of XIX century.

Currently, it has been consulted the publication of Gerda Nickel Maia (2004) that deserved attention by the sampling effort of the author and for presenting data referring to the nourishing use of the plants in the caatinga. It had been also performed a search in publications from ethnobotanical which had lists of useful plants, in order to locate species of nourishing use from caatinga.

Finally, for the species that composed the list of Andrade-Lima, it had been performed a search for documents that had nutritional information, thus to evaluate the nourishing and biotechnological potential of these species. Data about the indication of use of the mentioned species also had been consulted in the data base from the Northeastern Center of Information about Plants (CNIP 2010). 
Nunes et al. 2012. Caatinga plants with nutritional potential: a review from the work "Contribution to the study of the Flora from Pernambuco, Brazil" (1954) by Dárdano de Andrade Lima. Ethnobio Conserv 1:5

\section{Results and Discussion}

The results gotten in Andrade-Lima disclose considerable species richness. From the total of 98 species, 66 have indications of use, such as fodder, lumber, ornamental and nourishing use. In this last category it had been registered 14 plants as a whole, distributed among 11 families and 14 genre (Table 1), which corresponds in percentage terms approximately to $21 \%$ of the total of the useful species listed by the author. The species added to the main list, from the secondary sources considered (eight published articles in periodic and five books), had resulted in the addition of 31 nourishing species, endemic in the caatinga, included in 18 families and 31 genres (Table 1).

Facing these data is evident the importance of the native flora from the region regarding the analyzed resource, especially when evidenced the limitation regarding the number of research related to the theme. About this gap of studies carried out in the caatinga that are directed to the subject nourishing plants, Sampaio (2002), in his chapter "Use of the plants from caatinga", says there are many species consumed in the region, however without scientific records, over all those plants which are in the diet in an indirect way, in other words, when there is not primary intention in consuming them, as children and agriculturists who feed on the fruit of many local species.

Analyzing the cast of plants in the historical gradient, it has been evidenced that the times with higher number of nourishing species had been respectively the current period (22 spp.) and the contemporary (20 spp.). The records from XVII century had added only seven endemic species (Table 1). It is possible that the biggest number of species registered in the current period is attributed to the great number of enclosed ethnobotanical works among the secondary sources, since the review of information close to the local population is a rich source of information about the useful species.

Amongst the species registered in the works of the XVII century, five are shared with the other analyzed periods and three are exclusive, they are: Licania rigida Benth. (oiticica), Dioclea marginata Benth. (mucunã) and Oreodaphne tinctoria Arruda ex Rosenth. (catinga branca). Between the 50 s and 70 s decades, five species are cited exclusively in the period: Arachis pusilla Benth., Inga subnuda Salzm. (ingazeira), Manilkara rufula (Miq.) Lam. (maçaranduba), Schinopsis brasiliensis Engl. (braúna) and Annona marcgravii Mart. (araticum). Finally eight species are cited just in the works considered as current (2005-2010), they are: Anadenanthera colubrina (Vell.) Brenan var. cebil (Griseb.) Altshul (angico), Croton sonderianus Muell. Arg. (marmeleiro), Bauhinia cheilantha (Bong.) Steud. (mororó), Commiphora leptophloeos (Mart.) J.B. Gilletr. (imburana), Cordia leucocephala Moric (moleque duro), Pseudobombax marginatum St.-Hil. (barriguda), Syagrus coronata (Mart.) Becc. (uricuri) and Ximenia americana L. (Plum) (ameixa).

Although there is a considerable number of species whose register throughout the historical gradient only happens in a period, is not possible to affirm that have occurred "incorporations" or "deletions" of the nourishing use for these species, is most likely that methodological factors may be involved in the presence or absence of the register of use of a species in a given season. Besides, it is noteworthy that a plant has been registered in a given season; this does not imply that it in fact has been or is being used. 
Nunes et al. 2012. Caatinga plants with nutritional potential: a review from the work "Contribution to the study of the Flora from Pernambuco, Brazil" (1954) by Dárdano de Andrade Lima. Ethnobio Conserv 1:5

Table 1. Nourishing species from caatinga present in the bibliographic review between XVI century and the year 2010 .

\begin{tabular}{|c|c|c|c|c|}
\hline $\begin{array}{l}\text { Family } \\
\text { Scientific name }\end{array}$ & Common name & $\begin{array}{l}\text { Previous works } \\
(\mathrm{XVII} \text { and } \mathrm{XIX)}\end{array}$ & $\begin{array}{c}\text { Contemporary } \\
\text { works } \\
\left(1950^{\mathrm{s}}-70^{\mathrm{s}}\right)\end{array}$ & $\begin{array}{c}\text { Current } \\
\text { works } \\
(2005-2010) \\
\end{array}$ \\
\hline $\begin{array}{l}\text { Anacardiaceae } \\
\text { Spondias tuberosa Arruda } \\
\text { Schinopsis brasiliensis Engl. }\end{array}$ & $\begin{array}{l}\text { Imbuzeiro/Umbu } \\
\text { Baraúna/Braúna }\end{array}$ & $X$ & $\begin{array}{l}X \\
X\end{array}$ & $x$ \\
\hline $\begin{array}{l}\text { Annonaceae } \\
\text { Annona marcgravii Mart. }\end{array}$ & Araticum & & $X$ & \\
\hline $\begin{array}{l}\text { Arecaceae } \\
\text { Copernicia cerifera Mart. } \\
\text { Syagrus coronata (Mart.) Becc. }\end{array}$ & $\begin{array}{l}\text { Carnaúba } \\
\text { Uricuri }\end{array}$ & $X$ & $X$ & $x$ \\
\hline $\begin{array}{l}\text { Bombacaceae } \\
\text { Pseudobombax marginatum (A. } \\
\text { St.-Hil., Juss. \& Cambess.) A. } \\
\text { Robyns }\end{array}$ & Embiratanha & & & $X$ \\
\hline $\begin{array}{l}\text { Boraginaceae } \\
\text { Cordia leucocephala Moric. }\end{array}$ & Moleque duro & & & $X$ \\
\hline $\begin{array}{l}\text { Bromeliaceae } \\
\text { Bromelia laciniosa Mart. }\end{array}$ & Macambira & & $X$ & $X$ \\
\hline $\begin{array}{l}\text { Burseraceae } \\
\text { Commiphora leptophloeos (Mart.) } \\
\text { J.B. Gillett }\end{array}$ & Imburana & & & $\mathrm{X}$ \\
\hline $\begin{array}{l}\text { Cactaceae } \\
\text { Cereus jamacaru DC. } \\
\text { Pilosocereus gounellei (Weber) } \\
\text { Byles \& Rowley }\end{array}$ & $\begin{array}{l}\text { Mandacaru } \\
\text { Xique-xique }\end{array}$ & $X$ & $\begin{array}{l}X \\
X\end{array}$ & $\begin{array}{l}X \\
X\end{array}$ \\
\hline $\begin{array}{l}\text { Caesalpiniaceae } \\
\text { Bauhinia cheilantha (Bong.) } \\
\text { Steud. } \\
\text { Hymenaea courbaril L. } \\
\text { Bauhinia forficata Link }\end{array}$ & $\begin{array}{l}\text { Mororó } \\
\text { Jatobá } \\
\text { Mororó }\end{array}$ & & $\begin{array}{l}X \\
X\end{array}$ & $\begin{array}{l}x \\
x \\
X\end{array}$ \\
\hline $\begin{array}{l}\text { Capparaceae } \\
\text { Capparis jacobinae Moric. } \\
\text { Crataeva tapia L. }\end{array}$ & $\begin{array}{l}\text { Icó preto/lcó de } \\
\text { cavalo/Incó } \\
\text { Trapiá }\end{array}$ & & $\begin{array}{l}X \\
X\end{array}$ & $\begin{array}{l}X \\
X\end{array}$ \\
\hline $\begin{array}{l}\text { Chrysobalanaceae } \\
\text { Licania rigida Benth. }\end{array}$ & Oiticica & $X$ & & \\
\hline $\begin{array}{l}\text { Euphorbiaceae } \\
\text { Cnidoscolus phyllacanthus (Müll. } \\
\text { Arg.) Pax\& L. Hoffm. } \\
\text { Croton sonderianus Muell. Arg. }\end{array}$ & $\begin{array}{l}\text { Faveleira } \\
\text { Marmeleiro- } \\
\text { preto }\end{array}$ & & $x$ & $\begin{array}{l}X \\
x\end{array}$ \\
\hline $\begin{array}{l}\text { Fabaceae } \\
\text { Geoffroea spinosa Jacq. } \\
\text { Senna occidentalis (L.) Link } \\
\text { Arachis pusilla Benth. } \\
\text { Dioclea marginata Benth. }\end{array}$ & $\begin{array}{l}\text { Marizeiro } \\
\text { Manjerioba/ } \\
\text { Manjiroba }\end{array}$ & $X$ & $\begin{array}{l}X \\
X \\
X\end{array}$ & $x$ \\
\hline
\end{tabular}


Nunes et al. 2012. Caatinga plants with nutritional potential: a review from the work "Contribution to the study of the Flora from Pernambuco, Brazil" (1954) by Dárdano de Andrade Lima. Ethnobio Conserv 1:5

\begin{tabular}{|c|c|c|c|c|}
\hline Dioclea grandiflora Mart.ex Benth. & Mucunã & $\mathrm{X}$ & $\mathrm{x}$ & $\mathrm{X}$ \\
\hline $\begin{array}{l}\text { Family } \\
\text { Scientific name }\end{array}$ & Common name & $\begin{array}{l}\text { Previous works } \\
(\mathrm{XVII} \text { and } \mathrm{XIX)}\end{array}$ & $\begin{array}{l}\text { Contemporary } \\
\text { works } \\
\left(1950^{\mathrm{s}}-70^{\mathrm{s}}\right)\end{array}$ & $\begin{array}{c}\text { Current } \\
\text { works } \\
(2005-2010)\end{array}$ \\
\hline $\begin{array}{l}\text { Lauraceae } \\
\text { Oreodaphne tinctoria Arruda }\end{array}$ & Catinga branca & $\mathrm{X}$ & & \\
\hline $\begin{array}{l}\text { Mimosaceae } \\
\text { Anadenanthera colubrina (Vell.) } \\
\text { Brenan var. cebil (Griseb.) Altshul } \\
\text { Inga subnuda Salzm. }\end{array}$ & $\begin{array}{l}\text { Angico } \\
\text { Ingazeira }\end{array}$ & & $\mathrm{x}$ & $\mathrm{X}$ \\
\hline $\begin{array}{l}\text { Rhamnaceae } \\
\text { Ziziphus joazeiro Mart. }\end{array}$ & Juazeiro/ juá & & $\mathrm{x}$ & $\mathrm{X}$ \\
\hline $\begin{array}{l}\text { Sapotaceae } \\
\text { Sideroxylon obtusifolium (Roem. } \\
\text { \& Schult.) Penn. } \\
\text { Manilkara rufula (Miq.) Lam. }\end{array}$ & $\begin{array}{l}\text { Quixabeira } \\
\text { Maçaranduba }\end{array}$ & & $\begin{array}{l}X \\
x\end{array}$ & $\mathrm{X}$ \\
\hline $\begin{array}{l}\text { Olacaceae } \\
\text { Ximenia americana L. }\end{array}$ & Ameixa & & & $\mathrm{x}$ \\
\hline
\end{tabular}

Amongst the registered species Spondias tuberosa Arruda and Dioclea grandiflora Mart. ex Benth. had been only the common ones to the three analyzed periods. The reasons so that such species are always present in the literary registers are different. In the case of $S$. tuberosa, it is believed that this is due the fact that the plant be consumed in the semi-arid region and for this reason the register of its nourishing use becomes easy. The same does not happen with $D$. grandiflora, a species of emergency use, used in the past, at times of alimentary scarcity and therefore always it is remembered by the population of the region, what facilitates its rescue. According to Guinand and Lemessa (2000) people have understood emergency food, as the ones, that present the following features: 1 - nourishing plants of wild nature with emergency components: within this category are the plants with organs which are consumed at any time of the year, for example, fruit, but that have another organ consumed only at alimentary scarcity time, this another organ does not need to have the typical characteristics of a famine food; 2 - nourishing plants that attract additional categories of consumers during the periods of drought: are food that normally are consumed by a social group, for example, children that at scarcity time the adults begin to consume them and to collect them and 3 - Plants cultivated with emergency components: in this in case the plant has organs that are only consumed when there is great need, therefore it may compromise the survival of the main culture or even though to provoke the death of the plant.

The consumption in natura of the fruitful species is the register of bigger presence in the considered sources, although these species also present other preparation ways, and despite the environment hostility to limit the production and the offer of this part of the plant (Table 2). In the scope of the consumption of nourishing plants, it is believed that extrinsic factors to the environment may strongly influence in the choice of the species. These factors would be related to the mentioned cultural taboo and the influence of the governmental programs in the social-cultural questions, that promote a certain change in the consumption necessity of many plants for the local population, over all those species of difficult access or preparation. About the part of the plant, Figure 1 shows the panorama for the consulted sources, standing out the citations of use of the fruit in the contemporary 
Nunes et al. 2012. Caatinga plants with nutritional potential: a review from the work "Contribution to the study of the Flora from Pernambuco, Brazil" (1954) by Dárdano de Andrade Lima. Ethnobio Conserv 1:5

period. This fact does not mean that the fruit has been less consumed at other times; only the contemporary works had more complete information about the species. Additional information about the consumption way of the species is in Table 2.

Curiously in every analyzed lists the number of exotic species associated to the nourishing use had stood out, as in Piso and Marcgrave (1648 cited Pickel 2008) and Arruda Câmara (1982), where from the 21 and 28 species respectively cited, only five corresponded to native species from the caatinga in both works. Different situation occurred in the list of species presented by Maia (2004) and by AndradeLima (1954), this because both works exclusively deal with plants from the region. The great number of exotic nourishing species found in the works also justifies in the own description of the settling of the Northeastern region that in the first years after the arrival of the Portuguese in Brazil, represented a great entry point of products from Europe, including many species of plants.

Table 2. Nourishing species from caatinga present in the bibliographic review between XVII century and the year 2010, with parts of the consumed plant, consumption way and respective authors cited in a chronological order.

\begin{tabular}{|c|c|c|c|}
\hline $\begin{array}{l}\text { Family } \\
\text { Scientific name }\end{array}$ & Previous works & Previous works & Previous works \\
\hline \multicolumn{4}{|l|}{ Anacardiaceae } \\
\hline Schinopsis brasiliensis Engl. & $\begin{array}{c}\text { Fr }(1,3), \text { Ro (1), Le (1- } \\
\text { 3) [Piso e Marcgrave } \\
\text { (1648); Arruda } \\
\text { Câmara (1982)] }\end{array}$ & $\begin{array}{l}\text { Re (5) [Andrade- } \\
\text { Lima (1954)] }\end{array}$ & $\begin{array}{c}\operatorname{Fr}(1,2,3,4,10), \text { Ro } \\
\text { (6), Le (1) [Maia } \\
\text { (2004); Albuquerque } \\
\text { et al. (2005); Ferraz } \\
\text { et al. (2005); Lins } \\
\text { Neto et al. (2008)] } \\
\text { - }\end{array}$ \\
\hline \multicolumn{4}{|l|}{ Annonaceae } \\
\hline Annona marcgravii Mart. & - & $\begin{array}{c}\operatorname{Fr}(1)[\text { Braga } \\
(1976)]\end{array}$ & - \\
\hline \multicolumn{4}{|l|}{ Arecaceae } \\
\hline Syagrus coronata Becc. & $\begin{array}{c}\text { Fr (1-8), Wo (6), Al (1) } \\
\text { [Piso e Marcgrave } \\
\text { (XVII); Arruda } \\
\text { Câmara (1982)] } \\
\text { - }\end{array}$ & $\begin{array}{l}\text { Ro (9), Fr (1), } \\
\text { Pa (1) [Braga } \\
\text { (1976)] } \\
\text { - }\end{array}$ & $\begin{array}{l}\text { [Albuquerque et al. } \\
(2009)]\end{array}$ \\
\hline \multicolumn{4}{|l|}{ Bombacaceae } \\
\hline $\begin{array}{l}\text { Pseudobombax marginatum A. St.- } \\
\text { Hil. }\end{array}$ & - & - & $\begin{array}{c}{ }^{*} \text { Ro (6) [Maia } \\
(2004)]\end{array}$ \\
\hline \multicolumn{4}{|l|}{ Boraginaceae } \\
\hline Cordia leucocephala Moric & - & - & $\begin{array}{l}\text { [Albuquerque et al. } \\
(2005) \text { ] }\end{array}$ \\
\hline \multicolumn{4}{|l|}{ Bromeliaceae } \\
\hline Bromelia laciniosa Mart. & - & $\begin{array}{c}\text { Re, Ro (6) } \\
\text { [Andrade- } \\
\text { Lima (1954); } \\
\text { Braga (1976)] }\end{array}$ & - \\
\hline \multicolumn{4}{|l|}{ Burseraceae } \\
\hline $\begin{array}{l}\text { Commiphora leptophloeos (Mart.) } \\
\text { J.B. Gilletr }\end{array}$ & - & - & Fr (1) [Maia (2004)] \\
\hline Cactaceae & & & \\
\hline
\end{tabular}


Nunes et al. 2012. Caatinga plants with nutritional potential: a review from the work "Contribution to the study of the Flora from Pernambuco, Brazil" (1954) by Dárdano de Andrade Lima. Ethnobio Conserv 1:5

\begin{tabular}{|c|c|c|c|}
\hline Cereus jamacaru D. C. & $\begin{array}{c}\text { Fr (1) [Piso e } \\
\text { Marcgrave (1648)] }\end{array}$ & $\begin{array}{l}\text { Fr (1) [Andrade- } \\
\quad \text { Lima (1954)] }\end{array}$ & - \\
\hline $\begin{array}{l}\text { Pilosocereus gounellei (Weber) } \\
\text { Byles \& Rowley }\end{array}$ & - & $\begin{array}{c}\mathrm{Cl}(1,7) \text { [Braga } \\
(1976)]\end{array}$ & - \\
\hline \multicolumn{4}{|l|}{ Caesalpiniaceae } \\
\hline Bauhinia cheilantha (Bong.) Steud. & $\begin{array}{c}\text { [Arruda Câmara } \\
\qquad(1982)]\end{array}$ & - & $\begin{array}{l}\text { [Albuquerque et al. } \\
\text { (2005); Lucena et } \\
\text { al. (2007)] }\end{array}$ \\
\hline Hymenaea courbaril L. & - & $\begin{array}{l}\text { Fr (1) [Andrade- } \\
\text { Lima (1954)] }\end{array}$ & $\begin{array}{c}\text { [Ferraz et al. } \\
(2005)]\end{array}$ \\
\hline Bauhinia forficata Link & - & $\begin{array}{c}\text { Se (7) [Cesar } \\
(1956)]\end{array}$ & [Maia (2004)] \\
\hline \multicolumn{4}{|l|}{ Capparaceae } \\
\hline Capparis jacobinae Moric. & - & $\begin{array}{l}\text { Fr (1) [Andrade- } \\
\quad \text { Lima (1954); } \\
\text { Cesar (1956)] }\end{array}$ & $\begin{array}{l}\text { [Lucena et al. } \\
\quad(2008)]\end{array}$ \\
\hline $\begin{array}{l}\text { Family } \\
\text { Scientific name }\end{array}$ & Previous works & Previous works & Previous works \\
\hline Crataeva tapia L. & - & $\begin{array}{l}\operatorname{Fr}(1) \text { [Cesar } \\
\quad(1956)]\end{array}$ & $\begin{array}{c}\text { Fr }(1,3,4) \text { [Maia } \\
(2004) ; \\
\text { Albuquerque et al. } \\
\text { (2005); Ferraz et } \\
\text { al. (2005); Lucena } \\
\text { et al. (2007) }\end{array}$ \\
\hline \multicolumn{4}{|l|}{ Chrysobalanaceae } \\
\hline Licania rigida Benth. & $\begin{array}{l}\text { Se (1) [Arruda } \\
\text { Câmara (1982)] }\end{array}$ & - & - \\
\hline \multicolumn{4}{|l|}{ Euphorbiaceae } \\
\hline $\begin{array}{l}\text { Cnidoscolus phyllacanthus (Müll. } \\
\text { Arg.) Pax \& L. Hoffm. }\end{array}$ & - & $\begin{array}{l}{ }^{*} \mathrm{Fr}(6,8), \mathrm{Se} \\
(6,8.9)[\text { Andrade- } \\
\text { Lima }(1954)]\end{array}$ & Se [Maia (2004)] \\
\hline Croton sonderianus Muell. Arg. & - & $\begin{array}{l}\text { [Cesar (1956); } \\
\text { Braga (1976)] }\end{array}$ & $\begin{array}{c}\text { Se (8) [Maia } \\
(2004)]\end{array}$ \\
\hline \multicolumn{4}{|l|}{ Fabaceae } \\
\hline Arachis pusilla Benth. & - & $\begin{array}{c}\text { Se (1) [Braga } \\
(1976)]\end{array}$ & - \\
\hline Dioclea grandiflora Mart. ex Benth. & $\begin{array}{l}\text { Se (6) [Piso e } \\
\text { Marcgrave (1648)] }\end{array}$ & $\begin{array}{l}\text { Se (7) [Andrade- } \\
\quad \text { Lima (1954)] }\end{array}$ & - \\
\hline Dioclea marginata Benth. & $\begin{array}{c}\text { Se (6) [Piso e } \\
\text { Marcgrave (1648)] }\end{array}$ & - & - \\
\hline Geoffroea spinosa Jacq. Mari & $\begin{array}{c}\mathrm{Al}(6) \text { [Arruda Câmara } \\
\text { (1982)] }\end{array}$ & $\begin{array}{l}\text { Se }(7), \text { Fr }(1,2) \\
\text { [Andrade-Lima } \\
(1954) ; \text { Cesar } \\
(1956) ; \text { Braga } \\
\text { (1976); Lucena } \\
\text { et al. }(2007)]\end{array}$ & $\begin{array}{l}\text { [Ferraz et } \\
\text { al.(2005)] }\end{array}$ \\
\hline Senna occidentalis (L.) Link & - & - & $\begin{array}{c}\text { [Santos et al. } \\
\quad(2009)]\end{array}$ \\
\hline \multicolumn{4}{|l|}{ Lauraceae } \\
\hline $\begin{array}{l}\text { Oreodaphne tinctoria Arruda ex. } \\
\text { Rosenth. }\end{array}$ & $\begin{array}{l}\text { Ro (10) [Arruda } \\
\text { Câmara (1982)] }\end{array}$ & - & - \\
\hline \multicolumn{4}{|l|}{ Mimosaceae } \\
\hline $\begin{array}{l}\text { Anadenanthera colubrina (Vell.) } \\
\text { Brenan var. cebil (Griseb.) Altshul } \\
\text { Inga subnuda Salzm. }\end{array}$ & - & $\begin{array}{c}- \\
\text { Fr (1), Se (6) } \\
\text { [Andrade-Lima } \\
\text { (1954); Braga }\end{array}$ & $\begin{array}{c}\operatorname{Re}(1) \text { [Maia } \\
(2004)] \\
-\end{array}$ \\
\hline
\end{tabular}


Nunes et al. 2012. Caatinga plants with nutritional potential: a review from the work "Contribution to the study of the Flora from Pernambuco, Brazil" (1954) by Dárdano de Andrade Lima. Ethnobio Conserv 1:5

\begin{tabular}{l|c|c|c} 
& & $(1976)]$ & \\
\hline $\begin{array}{l}\text { Rhamnaceae } \\
\text { Ziziphus joazeiro Mart. }\end{array}$ & - & $\begin{array}{c}\text { Fr (1) [Andrade- } \\
\text { Lima (1954); } \\
\text { Cesar (1956); } \\
\text { Braga (1976)] }\end{array}$ & $\begin{array}{c}\text { Fr (1, 10) [Maia } \\
\text { (2004); } \\
\text { Albuquerque et } \\
\text { al. (2005); Ferraz } \\
\text { et al. (2005); } \\
\text { Lucena et al. } \\
\text { (2007); Lucena et } \\
\text { al. (2008); } \\
\end{array}$ \\
& & & $\begin{array}{c}\text { Albuquerque et al } \\
\text { (2009)] }\end{array}$ \\
\hline $\begin{array}{l}\text { Sapotaceae } \\
\text { Sideroxylon obtusifolium (Roem. \& } \\
\text { Schult.) Penn. }\end{array}$ & - & $\begin{array}{c}\text { Fr (1) [Andrade- } \\
\text { Lima (1954); } \\
\text { Braga (1976)] }\end{array}$ & $\begin{array}{c}\text { (2005); Lucena et } \\
\text { al. (2007)] }\end{array}$ \\
\hline
\end{tabular}

Table 2 continued

\begin{tabular}{l|c|c|c}
\hline $\begin{array}{l}\text { Family } \\
\text { Scientific name }\end{array}$ & Previous works & Previous works & Previous works \\
\hline Manilkara rufula (Miq.) Lam. & - & $\begin{array}{c}\operatorname{Fr}(1) \text { [Andrade- } \\
\text { Lima (1954)] }\end{array}$ & - \\
\hline $\begin{array}{l}\text { Olacaceae } \\
\text { Ximenia americana L. }\end{array}$ & - & - & $\operatorname{Fr~(1,3)~[Maia~}$ \\
$(2004)]$
\end{tabular}

Legend: $\mathrm{Part}$ of the consumed plant $(\mathrm{Al}=$ almond, $\mathrm{Fr}=$ fruit, $\mathrm{Cl}=$ cladode, $\mathrm{Le}=$ leaf, $\mathrm{Wo}=$ wood, $\mathrm{Pa}=$ palmetto, $\mathrm{Ro}=$ root, $\mathrm{Re}=$ resin, $\mathrm{Se}=$ seed $)$; Consumption way $(1=$ in natura, $2=$ cooked, $3=$ juice, 4 = candy, 5 = exudate, 6 = flour/dough, $7=$ toasted, $8=$ oil, $9=$ spice, $10=$ liquor, $11=$ couscous); ${ }^{*}$ Emergency use. For this study, it had been considered as emergency use species, those ones which have any feature that limit their consumption, such as: unpleasant taste, difficulties to prepare or collect, presence of any side effect when consumed, being this way only ingested when all other nourishing resources are not available anymore. Species whose consumption is limited only by cultural questions are not considered in this text as emergency food.

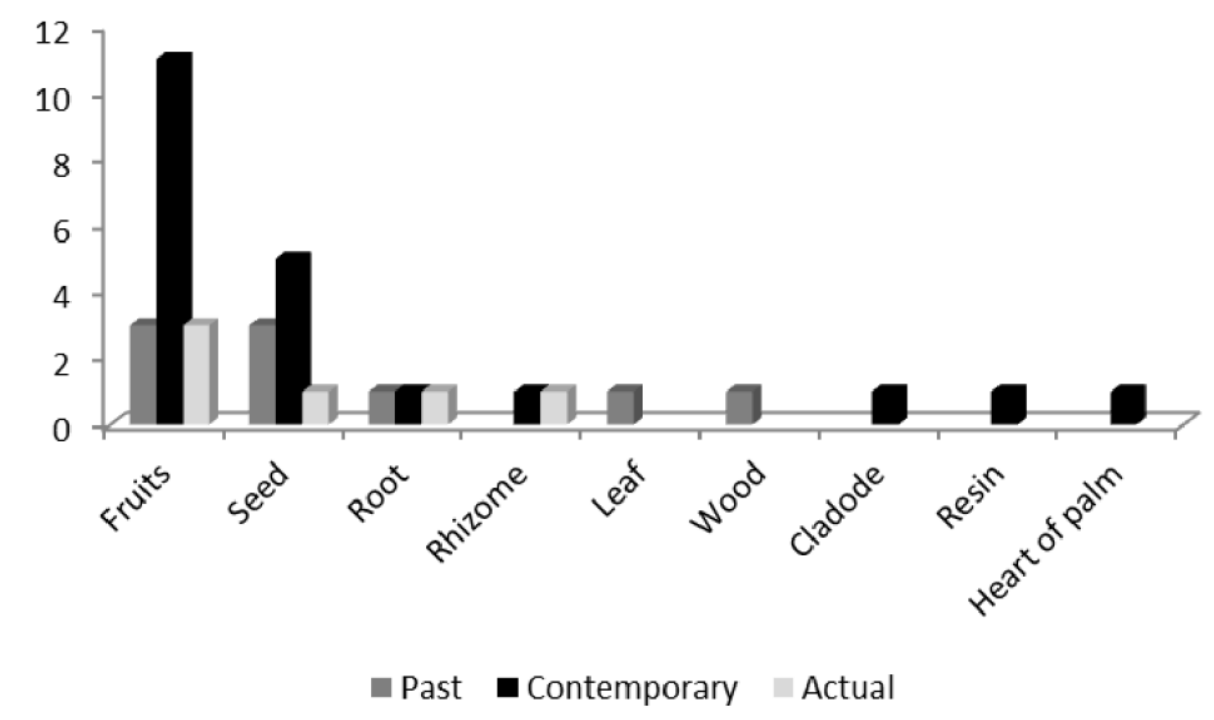

Figure 1. Ratio of the native species number from caatinga and the part of the plant consumed in different analyzed times.

Curiously in every analyzed lists the number of exotic species associated to the nourishing use had stood out, as in Piso and Marcgrave (1648 cited Pickel 2008) and Arruda Câmara (1982), where from the 21 and 28 species respectively cited, 
Nunes et al. 2012. Caatinga plants with nutritional potential: a review from the work "Contribution to the study of the Flora from Pernambuco, Brazil" (1954) by Dárdano de Andrade Lima. Ethnobio Conserv 1:5

only five corresponded to native species from the caatinga in both works. Different situation occurred in the list of species presented by Maia (2004) and by AndradeLima (1954), this because both works exclusively deal with plants from the region. The great number of exotic nourishing species found in the works also justifies in the own description of the settling of the Northeastern region that in the first years after the arrival of the Portuguese in Brazil, represented a great entry point of products from Europe, including many species of plants.

The great number of exotic nourishing species found in the works also justifies in the own description of the settling of the Northeastern region that in the first years after the arrival of the Portuguese in Brazil, represented a great entry point of products from Europe, including many species of plants. However, the low number of records of native nourishing plants, may be due the historical records of these uses by traditional communities are rare. Ochoa and Ladio (2011) observed in Patagonia the existence of few historical records between the XVI and XIX centuries. Thus, the lack of these records may limit the real information about the use of vegetal resources under a time scale. The researchers also observed that a small number of species had citations of use which have perpetuated in the consulted historical records and suggested that the environmental, social and cultural pressure had been the probable factors for this lack of knowledge about the native nourishing plants.

It is known that independent of the culture, country or region the exotic plants are inserted in the systems of traditional practices as a natural process of dynamics in the communities, it is noteworthy that the incorporation of new resources is an ordinary biogeographic process influenced by colonization, and it may be interpreted as an adaptive strategy of human populations because the environmental changes (temperature and rainfall), ecological (like the species extinction and biological pests) and cultural transformations (Torrejón and Cisternas 2002).

Although some authors believe that the insertion of exotic plants in the set of used plants characterizes a process known as cultural erosion or loss of traditional knowledge (e.g., Ladio and Lozada 2004) for Albuquerque et al. (2006) and Alencar et al. (2010) such species are used by the communities with the diversification intention, therefore they present chemical compounds that are not offered by native plants. Although the works which have mentioned the hypothesis of the diversification have been developed with medicinal plants, considering the results shown here for the nourishing plants is possible to say that there is a process of diversification of the alimentary diet similar to what happens with the medicinal plants, which leads to reflect about the necessity to extend the studies focused toward the nourishing resources. The incorporation of exotic plants in the list of nourishing resources brings up an interesting aspect in the dynamics of these species as the insertion of new resources, like it is observed in some regions from Patagonia, where there are records of high percentage of introduced plants, since colonization (Ochoa and Ladio 2011).

Despite the exotic plants to exert a strong influence on the population choice, it is noteworthy the necessity to better know the nourishing use of the native species from the region, especially the nutritional and productive potential of many of these species not only for local consumption, but also for production and exploitation in the agro industry and biotechnological processes. In order "to validate" the nourishing indication of these plants, it presents the following nutritional information about the plants listed in the central workmanship (Andrade-Lima 1954).

The species which deserves greater emphasis in the work is the umbuzeiro (S. tuberosa), plant of fundamental importance for the local population. Its use in the 
Nunes et al. 2012. Caatinga plants with nutritional potential: a review from the work "Contribution to the study of the Flora from Pernambuco, Brazil" (1954) by Dárdano de Andrade Lima. Ethnobio Conserv 1:5

feeding has historical records, being related by naturalists who had passed through the region. Amongst these are Sousa (1971), Martius (1840), and Gardner (1846). About this species which is considered as a sacred plant, the referred naturalists call the attention for the appreciation way of its fruit by the country person (sertanejo), in special for one of the preparation ways, the "umbuzada", which Martius classifies as a healthful and cooling food. The given importance of the plant is reflected in the present time, as described by Maia (2004), the use in natura of the fruit or in the most varied uses like juice, ice cream, candies, jellies, vinegars, wine and liquor the traditional "umbuzada". The same author also adds the use of the root in the eatable flour production, the green or fresh leaves may be used in salads. About roots, also known as tubers and cunca, according to Braga (1976) the country people use this part of the plant to relief thirst and hunger, being consumed in a similar form as the sugar cane. The roots contain proteins, crude fiber, ethereal extract, tannin, starch, sulphur, phosphorus, calcium and magnesium (Cavalcanti et al. 1999; Cavancanti and Resende 1999) and also can be prepared candies, jellies and even flour. The plant potatoes of the young plants of the umbuzeiro may also be consumed in natura and /or canned, called pickles. This form of exploitation of the umbuzeiro also can generate an alternative source of income, but should be always careful with excesses, once the exaggerated use of the umbu potatoes will possibly provoke damages to the renewal of the populations of the umbuzeiro from a region.

Mandacaru (Cereus jamacaru DC. - Cactaceae), also known as cardeiro, has as indication of use its fruit, consumed in natura (Andrade-Lima 1954). Recent works that evaluate the physical chemical properties of the fruit of mandacaru indicate to be appropriate to its form of consumption in natura, and add that the mentioned part of the plant has potential to be used in the industry and biotechnological processes, such as alcoholic fermentation, ascetic fermentation and in the production of leavendistilled (Oliveira et al. 2007; Almeida et al. 2009).

Besides the mandacaru Nascimento et al. (2011), has registered the knowledge about the nourishing use of other Northeastern species of cacti in communities from Brazil, for example: cumbeba or quipá (Tacinga inamoena K. Schum.), xique-xique (Pilocereus gounellei (F.A.C. Weber) Byles \& G.D. Rowley) and the facheiro (Pilosocereus pachycladus $F$. Ritter). In the case of quipá, the fruit is consumed in natura or as juice and has got pulp and pericarp with considerable mineral content as calcium, magnesium and potassium (Souza et al. 2007). In the case of the faxeiro and xique-xique may be consumed both fruit and the central core of the stem known as cladode (Nascimento et al. 2011). The fruit of xique-xique has got proteins and calcium (Barbosa et al. 2007) while the fruit of faxeiro stands out mainly because the flavonoids and the anthocyanins content (Nascimento et al. 2011), important compounds whose existence of antirust activity deserves to be investigated. The pulps of the cladode of both species have consistency which resembles the green papaya. Although the use of the pulp of these species is not widely spread out, it is used in some regions for candy preparation. In the case of the pulp of xique-xique, when dehydrated may be transformed into flour and be added to breads, cakes and biscuits, what can represent both an important strategy of alimentary complementation of the population as well as a source of alternative income (Almeida et al. 2007a,b; Clóvis 1957; Souza et al. 2007).

Baraúna (Schinopsis brasiliensis Engl.), belonging to the Anacardiaceae family, which Andrade-Lima mentions the possible use of the resin in the feeding of human beings. However, despite many authors affirm the multiplicity of uses of the questioned species, in any citation the information of Andrade-Lima was 
Nunes et al. 2012. Caatinga plants with nutritional potential: a review from the work "Contribution to the study of the Flora from Pernambuco, Brazil" (1954) by Dárdano de Andrade Lima. Ethnobio Conserv 1:5

corroborated (Albuquerque and Andrade 2002; Braga 1976; Cesar 1956; Ferraz et al. 2005; Lorenzi 1998; Lucena et al. 2007a,b; Maia 2004; Pio Correia 1984; Sampaio 2002; Santos et al. 2009).

In the case of the quixabeira (Sideroxylon obtusifolium (Gnaws. \& Schult.) Penn. - Sapotaceae) stands out its potential use for the production of wines and liquors, because the high fermentative power, besides the production of candies and compotes, due the content of ${ }^{\circ} \mathrm{Brix}(24,13)$, that gives favorable characteristics for the agro industry, although it has got low pulp yield (20.89\%), compensated by the high productivity of the plant $60 \mathrm{~kg} /$ day (Garrido et al. 2007).

The faveleira (Cnidoscolus phyllacanthus (Muell. Arg.) Pax \& K. Hoffm. Euphorbiaceae) has as eatable part its seeds. These seeds are rich in oil (40-70\%) light-colored, good nutritional features for having about $70 \%$ of saturated acids (linoleic acid) and still for containing calcium and iron (155 and 3,60 mg/100g, respectively), being the oil classified as high quality, pleasant taste, fine and low acidity, as indicated for the culinary (Maia 2004; Moura-Fé et al. 1977). The rinds also are important and have got calcium $(580 \mathrm{mg} / 100 \mathrm{~g})$, iron $(4,7 \mathrm{mg} / 100 \mathrm{~g})$ and total carbohydrates (70.40\%) in high ratio, according to Moura-Fé et al. (1977).

The juazeiro (Zizyphus joazeiro Mart. - Rhamnaceae) has a fruit rich in vitamin $\mathrm{C}$, is sufficiently nutritional and with pleasant flavor, being able to be consumed in natura when used in industry (Maia 2004; Silva et al. 2011).

The nourishing use of the icó preto (Neocalyptrocalyx longifolium (Mart.) Cornejo \& Iltis - Capparaceae), according to Andrade-Lima (1954) is restricted to the fruit that are commonly used in natura. On the other hand Cesar (1956) says that in critical periods of availability of alimentary resources, the fruit can be cooked with salt for the consumption. Not being found in literature most recent data about the nutritional content of this species.

Besides the icó, other species also are associated to the conditions of alimentary lack. This association of the consumption of a vegetal resource with periods of difficult survival strengthens in the popular imaginary the issue of the "cultural taboo". This fact may be evidenced in the stretch of the book "Geography of the Hunger" by Josué de Castro (1984, p. 220-221): "When the country men give up these exotic foods, it means that the drought martyrdom is already advanced and their misery has already reached the limits of their organic resistance. It is the last stage of their permanence in the desolate land, before become a migrant and going down to the heaps, searching for other lands less punished by the inclemency of the climate".

It is noteworthy that as the icó, other species are of restricted use to the period of drought, in other words, those consumed at critical moments, in which the long droughts provoke food scarcity (Andrade-Lima 1954). The disclosure of these plants is valid on several aspects, especially to valorize this wisdom, in view of its past importance guaranteeing in the survival of many people, and current, being able to be used in several ways, especially when attributed to techniques and biotechnological processes of improvement.

In this sense, one of the highlighted plants according to Castro and collaborators (1947) is the macambira (Bromelia laciniosa Mart. - Bromeliaceae), rich in starch, used to make flour from the bulb or potato, eatable part of the plant. The related authors had been the first ones to publish nutritional data of the macambira and other emergency plants in the article: "The Barbarian Foods from the Northeastern backwoods", in which stand out its importance in the feeding of human beings in agricultural communities from the caatinga, being the flour the main form of 
Nunes et al. 2012. Caatinga plants with nutritional potential: a review from the work "Contribution to the study of the Flora from Pernambuco, Brazil" (1954) by Dárdano de Andrade Lima. Ethnobio Conserv 1:5

preparation, rich in starch and other nutrients as proteins, minerals, sugars and fibers, besides iron and calcium, this last one in high concentration (1,62/100 mg).

Mucunã (Dioclea grandiflora Mart. ex Benth. - Fabaceae), common and abundant plant in the region, can be consumed by the population in the period of drought like flour form gotten from the roots, according to Andrade-Lima (1954) and Braga (1976). It is noteworthy that the use of this species marks a time of much hunger and malnutrition in Northeastern Brazil, as recorded by the scientists Josué de Castro, Gilberto Freyre and Nelson Chaves in the 40s and 80s decades, the use of mucunã bound to the malnutrition of the Northeastern people. In any case the studies at the time pointed out by Castro (1984) tell the nutritional importance of the species as a valuable resource of combat to the hunger, although there is controversies which may be better observed in the publication of Vasconcelos (2001) titled in "Hunger, eugenics and constitution of the nutrition field in Pernambuco: an analysis of Gilberto Freyre, Josué de Castro and Nelson Chaves". Currently, similar uses had been registered by Albuquerque and Andrade (2002), however without more nutritional descriptions for species in the consulted bibliography.

Another important emergency food from the caatinga is xique-xique (Pilosocereus spp. - Cactaceae), whose marrow of the cladode can be used to make flour or consumed baked. According to Castro et al. (1947) to prepare flour, it is necessary to remove the thorns out of the rods of the plants until remains only "marrow case" that is constituted by the marrow coated by a woody layer. Made this, this marrow is baked in live coals during 10 to 15 minutes. Hereafter the woody rind is removed and the marrow may be transformed into whitish, odorless and dull flour. Still according to the authors the xique-xique flour presents low content of protein and starch $(0.73 \mathrm{~g}$ and $1.37 \mathrm{~g}$ respectively in $100 \mathrm{~g}$ of the product).

\section{Conclusions}

The total number of nourishing species represents a significant percentage regarding the useful plants of the region from caatinga. However, to justify the low citation number of past use is necessary a more detailed analysis to elucidate the question.

The real consumption of plants may be related to several factors, as a change in the alimentary habits under the influence in the "contemporary way of life", that makes the new generations did not perpetuate the way to identify, to gather and to process the native species from the caatinga. Also may affect the consumption of vegetable species, the social economic aspects, with higher access to products already processed and the negative connections, in other words, the local perception that the native foods are symbol of poverty in the past. However, to say that the use of native nourishing plants from caatinga is rare or limited may be not truth, once we cannot say that there is low preference regarding the use of these species or if the limitation in the research focused toward this purpose hide this information.

The Anacardiaceae family was the only one present in all historical periods, due to a single species, $S$. tuberosa (umbú). Thus, it may be said that this species from the caatinga cited by different authors, demonstrates that a shared alimentary culture which is shared throughout time.

Some of the native plants from the caatinga have recognized their nutritional value. Despite this proven reality, the number of research focused toward the nutritional analysis is still restricted. It has been recommended that, more research is 
Nunes et al. 2012. Caatinga plants with nutritional potential: a review from the work "Contribution to the study of the Flora from Pernambuco, Brazil" (1954) by Dárdano de Andrade Lima. Ethnobio Conserv 1:5

carried out this Brazilian tropical domain, the caatinga. It must be prioritized the register of information that deal with the forms of feeding of a people who in general may be characterized by a low purchasing power, of great ethnic diversity (aboriginal, maroons and agricultural communities) that, inserted in an environment equally diverse in its biology, multiply the forms of knowledge and use about this environment.

\section{Acknowledgements}

To FACEPE (Support Foundation to Technology and Science from Pernambuco State) by granting the first author of the work with a scholarship; and to CNPq (National Council of Technological and Scientific Development) by providing Masters and Post-doctorate grants for the authors I.S. Feitosa and M.F.T. Medeiros.

\section{References}

Albuquerque UP, Andrade LHC (2002) Uso de plantas em uma comunidade rural no semi-árido do estado de Pernambuco, município de Alagoinha (Nordeste do Brasil). Interciência 27(07):336-346.

Albuquerque UP, Lucena RFP, Monteiro JM, Florentino ATN, Almeida CFCBR (2006) Evaluating two quantitative ethnobotanical techniques. Ethnobotany Research Applications 4(1):51-60.

Albuquerque UP, Monteiro JM, Ramos MA, Amorim ELC (2007) Medicinal and magic plants from a public market in Northeastern Brazil. Journal of Ethnopharmacology 110:76-91.

Albuquerque UP, Araújo TAS, Ramos MA, Nascimento VT, Lucena RFP, Monteiro JM, Alencar NL, Araújo EL (2009) How ethnobotany can aid biodiversity conservation: reflections on investigations in the semi-arid region of NE Brazil. Biodiversity and Conservation 18:127-150.

Alencar NL, Araújo TAS, Amorim ELC, Albuquerque UP (2010) The inclusion and selection of medicinal plants in traditional pharmacopoeias-evidence in support of the diversification hypothesis. Economic Botany 64(1):68-79.

Almeida CFCBR, Albuquerque UP (2002) Uso e conservação de plantas e animais medicinais no estado de Pernambuco (nordeste do Brasil): um estudo de caso. Interciência 27:276-285.

Almeida MM, Silva FLH, Conrado LS, Freire RMM, Valença AR (2007a) Caracterização Física e físico-química de frutos do mandacaru. Rev. Ciên. Agron. 38(4):440-443.

Almeida CA, Figueirêdo RMF, Queiroz AJM, Oliveira FMN (2007b) Características físicas e químicas da polpa de xiquexique. Physical and chemical characteristics of xiquexique pulps. Rev. Ciên. Agron. 38(4):440-443.

Almeida, MM, Silva FLH, Conrados LS, Freire RMM, Valença AR (2009) Caracterização física e físico-química de frutos do mandacaru. Revista Brasileira de Produtos Agroindustriais 11:(1):15-20.

Andrade-Lima D (1954) Contribution to the Study of the Flora of Pernambuco, Brazil. Monografia I. Universidade Federal Rural de Pernambuco, Recife, Pernambuco, Brazil.

Andrade-Lima D (1982) IN MEMORIAM (1919-1981). New York Botanical Garden. Brittonia 34(3):351-354. 
Nunes et al. 2012. Caatinga plants with nutritional potential: a review from the work "Contribution to the study of the Flora from Pernambuco, Brazil" (1954) by Dárdano de Andrade Lima. Ethnobio Conserv 1:5

Arruda Câmara MA (1982) Manuel Arruda da Câmara: obras reunidas. Fundação de Cultura Cidade do Recife, Recife, Pernambuco, Brazil.

Barbosa AS, Araújo AP, Canuto TM, Dias SL, Cavalcanti MBA, França VC (2007) Caracterização físico-química do xique-xique encontrado no semi-árido Nordestino. Congresso Norte-Nordeste de química, Natal - RN.

Braga R (1976) Plantas do Nordeste: especialmente do Ceará. 4 ed. ESAM, Natal, Rio Grande do Norte, Brazil.

Castro J, Pechnik E, Parahim O, Matoso ÍV, Chaves JM (1947) Os "Alimentos bárbaros" dos sertões do Nordeste. Arquivos Brasileiros de Nutrição 3(2):529

Castro J (1984) Geografia da fome. Clássico das Ciências Sociais no Brasil (O dilema brasileiro: pão ou aço). 10 ed. Antares, Rio de Janeiro, Brazil.

Cavalcanti NB, Resende GM, Delgado LB (1999) Desenvolvimento do umbuzeiro (Spondias tuberosa Arruda) na região semi-árida do Nordeste brasileiro. Ciência e Agrotécnica 23(1):212-213.

Cavalcanti NB, Resende GM (1999) Extrativismo vegetal como fator de absorção de mão-de-obra e geração de renda: o caso do imbuzeiro (Spondias tuberosa Arruda.). Paper Presented at the $37^{\circ}$. Congresso Brasileiro de Economia e Sociologia Rural. Foz do Iguaçú, Brazil.

Centro Nordestino de Informação sobre Planta (CNIP) (2010) [http://www.cnip.org.br] Accessed 24 May 2010.

César G (1956) Curiosidades da nossa flora. Imprensa Oficial de Recife, Recife, Pernambuco, Brazil.

Ferraz JS, Albuquerque UP, Meunier IMJ (2005) Conhecimento sobre espécies lenhosas úteis da mata ciliar do Riacho do Navio, Floresta, Pernambuco. Zonas Áridas 9:27-39.

Gardner G (1846) Contributions towards a Flora of Brasil, being the characters of several New Species of Compositae, belonging to the tribe Euphorbiaceae. Lond. Jour. Bot.: 455-491.

Garrido MS, Soares ACF, Sousa CS, Calafante PLP (2007) Características física e química de frutos de quixaba Sideroxylon obtusifolium Penn. Revista Caatinga 20(4):34-37.

Giulietti AM (2004) Diagnóstico da vegetação nativa do bioma Caatinga. In: Silva JMC et al. (eds.) Biodiversidade da Caatinga: áreas e ações prioritárias para a conservação. MMA, Brasília.

Guinand Y, Lemessa D. (2000) Wild-food Plants in Southern Ethiopia: Reflections on the role of 'faminefoods' at a time of drought. UN-EUE Survey, Addis Ababa.

Ladio AH, Lozada M (2004) Summer Cattle Transhumance and Wild Edible Plant Gathering in a Mapuche Community of Northwestern Patagonia. Human Ecology 32(2):225-240.

Lins Neto EMF, Peroni N, Maranhão CMC, Maciel MIS, Albuquerque UP (2012) Physical and Chemical Characterization of Spondias tuberosa Arruda Fruit from Different Caatinga Landscapes in Altinho-PE. The Natural Products Journal 2:156-160.

Lorenzi H (1998) Árvores brasileiras: manual de identificação de plantas arbóreas nativas do Brasil. 2 ed. Editora Plantarum, São Paulo, Brazil.

Lucena RFP, Albuquerque UP, Monteiro JM, Almeida CFCBR, Florentino ATN, Feitosa JS (2007a) Useful Plants of the Semi-Arid Northeastern Region of 
Nunes et al. 2012. Caatinga plants with nutritional potential: a review from the work "Contribution to the study of the Flora from Pernambuco, Brazil" (1954) by Dárdano de Andrade Lima. Ethnobio Conserv 1:5

Brazil - A Look at their Conservation and Sustainable Use. Environmental Monitoring and Assessment 125:281-290.

Lucena RFP, Nascimento VT, Araújo EL, Albuquerque UP (2007b) Local Uses of Native Plants in an Area of Caatinga Vegetation (Pernambuco, NE Brazil). Ethnobotany Research \& Applications 6:003-013.

Maia GN (2004) Caatinga: árvores e arbustos e suas utilidades. Dandz Computação Gráfica e Editora, São Paulo, Brasil.

Martius CFP von, Eichler AW, Urban I (1840) Flora Brasiliensis. Monachii et Lipsiae.

Meyer-Rochow VB (2009) Food Taboos: Their Origins and Purposes. Journal of Ethnobiology and Ethnomedicine 5:18-27.

Ministério do Meio Ambiente (MMA) (2002) Avaliação e ações prioritárias para a conservação da biodiversidade da Caatinga. Universidade Federal de Pernambuco/ Fundação de Apoio ao desenvolvimento da conservação do Brasil. Fundação Biodiversidade: Embrapa: semi-árido, Brasília, Goiás, Brasil.

Missouri Botanical Garden's VAST (Vascular Tropicos) nomenclatural database W3 Tropicos. (2010). [http://www.mobot.mobot.org/w3t/Search/vast.html] Accessed 10 May 2010.

Monteiro JM, Albuquerque UP, Lins Neto EMF, Araújo EL, Amorim ELC (2006) Use patterns and knowledge of medicinal species among two rural communities in Brazil's semi-arid northeastern region. Journal of Ethnopharmacology 105:172-186.

Moura-Fé JA, Holanda LFF, Martins CB, Maia GA (1977) Estudos tecnológicos da faveleira (Cnidoscolus phyllacanthus Mart. Pax ex Hoffm.). Ciência Agronômica 7(1):33-37.

Nascimento VT, Souza LG, Alves AGC, Araújo EL, Albuquerque UP (2009) Rural fences in agricultural landscapes and their conservation role in an area of caatinga (dryland vegetation) in Northeast Brazil. Environment, Development and Sustainability 11(5):1005-1029.

Nascimento VT, Moura NP, Vasconcelos MAS, Maciel MIS, Albuquerque UP (2011) Chemical characterization of native wild plants of dry seasonal forests of the semi-arid region of northeastern Brazil. Food Research International 44(7):2112-2119.

Ochoa JJ, Ladio AH (2011) Pasado y Presente del uso de plantas silvestres com órganos de almacenamiento subterráneos comestibles em la Patagonia. Bonplandia 20(2):265-284.

Oliveira MFN, Feitosa MRF, Queiroz AJM, Almeida CA (2007) Caracterização físico-química das polpas dos ramos do mandacaru. Revista Caatinga 20(4):89-92.

Pickel BJ (2008) Flora do Nordeste do Brasil segundo Piso e Marcgrave no século XVII. Argus Vasconcelos de Almeida (Editor). EDUFRPE, Recife, Pernambuco, Brasil.

Pio Correia M (1984) Dicionário das plantas úteis do Brasil e das exóticas cultivadas. 6 vols. IBDF, Rio de Janeiro, Brasil.

Piso W, Marcgrave G (1648) Historia Naturalis Brasiliae: in qua non tantum plantæ et animalia, sed et indigenarum morbi, ingenia et mores describuntur et iconibus supra quingentas illustrantur. Amsterdam: Elsevier. Editado e anotado por Johannes de Laet. [http://biblio.etnolinguistica.org/marcgrave-1648-historia] Accessed 18 January 2011. 
Nunes et al. 2012. Caatinga plants with nutritional potential: a review from the work "Contribution to the study of the Flora from Pernambuco, Brazil" (1954) by Dárdano de Andrade Lima. Ethnobio Conserv 1:5

Ramos MA, Medeiros PM, Almeida ALS, Feliciano ALP, Albuquerque UP (2008) Can wood quality justify local preferences for firewood in an area of caatinga (dryland) vegetation. Biomass \& Bioenergy 32:503-509.

Rochow M, Benno V (2009) Food Taboos: Their Origins and Purposes. Journal of Ethnobiology and Ethnomedicine 5:18-27.

Sampaio EVSB (2002) Uso das plantas da Caatinga. In: Sampaio EVSB, Giulietti AM, Virgínio J, Gamarra-Rojas CFL (eds) Vegetação e flora da Caatinga. APNE /CNIP, Recife.

Santos JP, Araújo EL, Albuquerque UP (2008) Richness and distribution of useful woody plants in the semi-arid region of northeastern Brazil. Journal of Arid Environments 72:652-663.

Santos LL, Ramos MA, Silva SI, Sales MF, Albuquerque UP (2009) Caatinga Ethnobotany: Anthropogenic Landscape Modification and Useful Species in Brazil's Semi-Arid Northeast. Economic Botany 63(4):363-374.

Silva ACO, Albuquerque UP (2005) Woody medicinal plants of the caatinga in the state of pernambuco (Northeast Brazil): floristic and ethnobotanical aspects. Acta Botanica Brasilica 19(1):17-26.

Silva LR, Barreto NDS, Batista PF, Araújo FAR, Morais PLD (2011) Caracterização de frutos de cinco acessos de juazeiro (Zizyphus joazeiro Mart.). Revista Brasileira de Produtos Agroindustriais 13(1):15-20.

Sousa GS (1971) Tratado descritivo do Brasil em 1587. Cia. Ed. Nacional, EDUSP São Paulo, Brazil (Coleção Brasiliana, vol 117 - Original de 1587).

Souza ACM, Gamarra-Rojas G, Andrade SAC, Guerra NB (2007) Características físicas, químicas e organolépticas de quipá (Tacinga inamoena, Cactaceae). Revista Brasileira de Fruticultura 29(2):292-295.

Tabarelli M, Vicente A (2002) Lacunas de conhecimento sobre as plantas lenhosas da caatinga. In: Sampaio EVSB, Giulietti AM, Virgínio J, GamarraRojas CFL (eds) Vegetação e Flora da Caatinga. APNE /CNIP Recife.

Torrejón F, Cisternas M (2002) Alteraciones del paisaje ecológico araucano por la asimilación mapuche de la agroganadería hispano-mediterránea (siglos XVI y XVII). Revista Chilena de Historia Natural 75:729-736.

Vasconcelos FAG (2001) Fome, eugenia e constituição do campo da nutrição em Pernambuco: uma análise de Gilberto Freyre, Josué de Castro e Nelson Chaves. História, Ciências, Saúde 8(2):315-319. 